\title{
What Should a Doctor Look Like?
}

\author{
Diana Zhong, MD
}

Division of Infectious Diseases, Johns Hopkins University School of Medicine, 1830 E. Monument St, Baltimore, MD, USA

J Gen Intern Med 36(10):3234-5

DOI: $10.1007 /$ s11606-021-06949-5

(C) Society of General Internal Medicine 2021

I scrutinize myself in the mirror for countless hours. White coat or not? Dress or pants? Less makeup? More makeup? Glasses? A badge emblazoned with "DOCTOR" in large white all-caps on a red background?! I've tried every permutation in an attempt to garner respect in the workplace; I guess I'm just not what a doctor looks like. As a young woman of color in medicine, I feel unexceptional for my multitude of experiences on the receiving end of racism and sexism - and I am hardly alone. I face incidents with such predictability that my colleague coined the term "daily microaggression." One a day keeps the doctor dismayed.

As an Asian woman, racism and sexism are intimately intertwined experiences. I recall the innumerable comments since childhood, mocking my name and my eyes. Naively, I hoped perhaps becoming a working professional would lessen the incidents over time, and that my workplace would be a sanctuary of respect. How can my appearance as a young Asian woman-so ubiquitous in medicine and the world - induce so many invisible scars, yet impart such palpable insecurity? The erosion of confidence is pervasive. It begins: I don't look like a doctor; it becomes: I don't feel like one, either.

The inescapable. Numerous patients informed me they like "exotic" and "Oriental" girls. As a medical student, an older male patient suggestively inquired, "Would your parents allow you to date someone not Oriental?" In residency, a patient declared, "There's something special about Asian women," and proceeded to list some "special" traits. My ex-favorite Spanish interpreter divulged how he "loved everything about Asia and Asians" and said he "always wanted Asian babies." On the fellowship interview trail, I received benevolent advice that three other young Asian women and I all "share superficial characteristics and should find ways to distinguish ourselves," and accordingly we ought to "wear our nametags prominently" and coordinate "different hairstyles"-a double-edged sword that implied faculty could not otherwise tell us apart.

Received May 9, 2021

Accepted May 20, 2021

Published online June 25, 2021
The world through a racialized lens. When I struggled to understand thick American regional accents, patients speculated whether I knew English (I'm from the mid-Atlantic). Strength is not always in numbers; while caring for a patient alongside two Asian male colleagues, he called us "Chinamen." People frequently challenge "where I'm really from" and assert how much I look exactly like so-and-so other Asian person. A patient queried my "nationality" (perhaps he meant ethnicity) but guessed before I could answer. I've been told my one-syllable last name is "unusual," "difficult to pronounce," and that there are "just so many variations" of Asian names.

The violation of bodily autonomy, the crossing of boundaries. The patient who stroked my hair. The medical school classmate who grabbed my butt at a party; the co-resident who did the same. The co-resident who I rebuffed for a kiss five times in one night - because the first "no" was not enough. The university that shamed a respected Asian woman physician for taking maternity leave twice as junior faculty-even when she worked from her laptop in L\&D during both deliveries. The program director and countless interviewers who asked when I was getting married, when I was having children. The patients who moan sounds of pleasure while being physically examined. The patients who supersede my medical assessment to ask if I have a "honeybun." The employee in the cafeteria line who deemed me "cute in my blue scrubs," then stalked me around the hospital despite my increasingly visible discomfort. He interrupted me in rare moments of peace when I dared to sit in public spaces. At least I have "great legs."

The incessant sexualization, infantilization, or both. A patient who proclaimed that I'm too pretty to be a doctor, as if they were mutually exclusive attainments. A patient announced that I gave him "pretty-itis"-in front of his wife-I was mortified and mostly offended on her behalf. While shaking a patient's hand, he commented on my "beautiful slender hands" and pondered aloud why there wasn't a ring on my left hand. (There is now, but it hasn't been a protective factor). I'm a "girl," "honey," or "doll”" nearly as often as I am a "doctor." When I was catcalled "sexy doctor" while wearing scrubs at a bus stop, my first instinct was pleasant surprise that the man believed I could be a physician! He knows what a doctor looks like!

The diminishing of my accomplishments. I was interrogated at the light rail station about whether I "like wearing scrubs for leisure" after leaving a leisurely 30-hour shift at the hospital. When I was called "Miss" after clearly introducing myself 
by name (I was even wearing my white coat and pants that day). When I rounded on a patient daily for two weeks, but his family interjected to instead gesture toward and request an update from "the doctor," my male co-resident who had never met them. It permeates all domains, from constant midsentence interruptions to disregarding medical judgment. I panic as I relive my fear for a man's life, after a nurse refused to administer Ativan despite him floridly withdrawing from alcohol, tremulous and tachycardic to the 140 s, even after I calmly explained my rationale. It is both embarrassing and heartwarming when male colleagues back me up. I feel sheepish that I need defending, but grateful that my hurt is recognized. I muse about the male co-resident who was so upset at a patient's derision of me that he sternly spoke back to her-she filed a patient relations complaint against him.

The impact on our learners. A medical student shadowed me while I assessed patients as a senior resident. I was already so timid, yet she watched me get berated, eyes rolled at me, and my orders refused. I accidentally peeked behind the wrong curtain in the emergency department and received the admonishment, "Don't you even check a patient's room number before you go in?" The medical student actually cried at the end of the shift, appalled at the contrast between what she just witnessed and how staff treated male residents on her prior rotation. She was distraught and enraged, brooding over how she should have retaliated at everyone who treated me poorly. She did not comprehend my patience or my perseverance. She speculated that our shift was a harbinger to her bleak future as a woman in medicine. I comforted her with uncertain hope for a brighter future, but I hadn't found my voice yet. With shared understanding, she half-joked that she was at least very tall and white, so could probably garner a bit more respect than me.

I cared for a patient whose family inflicted months of verbal abuse and violent posturing toward staff. During a unit-wide debrief meeting, the ethics facilitator said we "need to depersonalize the abuse" from patients. The abuse. People corner my Asian women friends on the seemingly progressive streets of Seattle, San Francisco, and Boston; it was once catcalling, but is now blaming us for the coronavirus pandemic, coughing on us, and spitting in our faces. Why do they wait until we're alone? What happens the next time I am cornered?

Seven years into my medical career and many tears later, I found myself in my first role of attending-hood. Although I am slow to master resiliency, I am learning vulnerability. I had long grappled with finding my voice, but quickly discovered my meek words have surprisingly phenomenal power. I was sexually harassed by a patient during my very first shift as an attending. My badge even had the fancy words, "Attending Physician"! Nothing had changed, and nothing was ever going to change. In my frenzy, I vented to the residents and medical students. My sub-intern, a Latina medical student, later confided that my openness and willingness to discuss my struggles helped her immensely; she realized that her hurt was justified, that her experiences were not a reflection of her capabilities, and that she was not alone. Despite our shared adversity, my heart was further warmed when she revealed that my mentorship affirmed her desire to enter academic medicine - so that she could mentor others as I had mentored her. Heck, could my frazzled words truly carry so much weight?

Yet, others' words carry weight to a burdensome degree. The medical student shared that her fellow Mexican-American student was told, "I can't believe they allow illegals into medical school!" My Indian-American medical student classmate was called a "sandn*****." My black male co-resident was instructed, "Son, doctors can't wear their hair like that" when he kept his hair natural. They have all wondered, What should a doctor look like?

I have since moved cross-country and started fellowship. I still think of that Latina medical student often. She had never before seen a young woman physician of color speak openly about gender and race. But she also distinctly admired the rest of me - she awed at how I kept my long hair down and wore dresses in the hospital, how I didn't stifle my expressions of femininity even when the world implored me to. Since then, more students and residents have expressed that they aspired to be like me, sharing handwritten cards of gratitude, perfectly crafted text messages with empowering emojis, and scrumptious baked goods. To them, I am strong. To them, I became one more normal—no, wonderful—variation of what a doctor looks like.

Corresponding Author: Diana Zhong, MD; Division of Infectious Diseases, Johns Hopkins University School of Medicine, 1830 E. Monument St, Baltimore, MD 21205, USA (e-mail: dzhong5@jhmi. edu).

Publisher's Note: Springer Nature remains neutral with regard to jurisdictional claims in published maps and institutional affiliations. 